\title{
Las figuraciones del Oriente en las redes intelectuales de América Latina
}

\author{
Pilar Maria Parot Varela ${ }^{1}$
}

BERGEL, Martín. El Oriente desplazado: Los intelectuales y los orígenes del tercermundismo en la Argentina. Buenos Aires: Universidad Nacional de Quilmes, 2015. 354 páginas.

El presente trabajo es fruto de la tesis de doctorado del historiador argentino Martín Bergel, defendida en el año 2010 y publicada bajo el formato de libro en el año 2015 por la editorial de la Universidad de Quilmes. En este libro el autor reconstruye el surgimiento y la difusión de una imagen positiva de Oriente, consolidada en la década de 1920, que invierte la visión clásica, dominante durante el siglo XIX y principios del siglo XX, según la cual el Oriente representa una serie de valores negativos como la barbarie, el atraso y la violencia. Bergel sitúa a este fenómeno intelectual y cultural, al que denomina "orientalismo invertido", como un antecedente de lo que durante la década de 1950 se difundirá en Argentina como tercermundismo.

La particularidad del libro reside en que el autor propone una categoría histórica que supone una valoración diferente de aquel conjunto de imágenes y generalizaciones referidas al Oriente que el intelectual palestino Edward Said englobó bajo el término “orientalismo". Este concepto supone, para Said, una proyección occidental sobre Oriente que se plasma en una serie de significados, asociaciones y connotaciones orientadas a ejercer una dominación sobre el mismo. A través del "orientalismo invertido", Bergel logra articular un minucioso e interesante trabajo de investigación que alterna enfoques más descriptivos con otros más argumentativos y que confiere un papel fundamental a la dimensión material -libros, crónicas de viajes, revistas, correspondencias, intercambios epistolares, traducciones, fotografías, entre otras- que asiste a la circulación de ideas e imágenes sobre el Oriente generada por intelectuales de diversos lugares del campo cultural y político.

\footnotetext{
${ }^{1}$ Licenciada en Filosofía por la Universidad de Buenos Aires. Doctoranda en Filosofía por la misma universidad. E-mail: pilarparotv@gmail.com
}

\section{GANPHLAC}


Es preciso señalar que el eje de la discusión no apunta a una revisión sobre la verdad empírica contenida en el concepto de Said sino sobre la dinámica histórica que posibilita un giro valorativo a esas representaciones y que permite al autor gestar este concepto y situarlo en un tiempo y espacio determinado. Por ello, Bergel repara en las redes que entretejen las relaciones entre intelectuales orientales, europeos y latinoamericanos y que permiten la propagación de estas imágenes relativas al Oriente y su revalorización.

La primera concepción sobre el Oriente que el autor rastrea en Argentina es la articulada por Domingo F. Sarmiento, a la cual conceptualiza bajo el término "matriz sarmientina", que supone una visión negativa sobre el Oriente y alcanza un lugar dominante entre los intelectuales de la elite letrada argentina. Las crónicas de viaje de Lucio V. Mansilla, en las que el tópico del fanatismo religioso es retomado de modo recurrente, y el relato de los viajes de Pastor Obligado, plagado de múltiples detalles acerca de las particularidades del mundo oriental, no sólo perpetúan la "matriz sarmientina" durante la segunda mitad del siglo XIX, sino también constituyen el signo de pertenencia a una elite que ha logrado el privilegio de acceder a realidades poco frecuentadas.

La connotación negativa de las referencias al Oriente no reside en el carácter estético-exotista señalado por el romanticismo europeo sino en su imagen como un contramodelo del proyecto de sociedad moderna y civilizada que Sarmiento persigue. La "matriz sarmientina", que inscribe al Oriente dentro de los márgenes del atraso y la barbarie, "llega inalterada en sus componentes esenciales al ensayo positivista de fin de siglo" (BERGEL, 2015, p. 67), e incluso principios del siglo XX, lo cual puede advertirse en la imagen de Rusia construida por Ernesto Quesada en Un invierno en Rusia, y en la inferioridad racial atribuida a las poblaciones africanas en las crónicas de viaje de José Ingenieros en 1905. Asimismo, la analogía entre España y el mundo árabe resulta uno de los tópicos de mayor divulgación entre los intelectuales argentinos de ese período.

Este conjunto de valoraciones acerca del Oriente, que Bergel analiza en el capítulo I, comienza a modificarse paulatinamente en el capítulo II, a partir de la confluencia de tres fenómenos que, entre 1880 y 1914, establecen un vínculo entre Argentina y el mundo internacional y sientan las bases para la consolidación del

\section{GANPHLAC}


espiritualismo y el antiimperialismo: el sistema de prensa moderno, fruto del desarrollo de la red telegráfica y las agencias internacionales de noticias, que motiva un debate público en torno al avance europeo sobre los pueblos africanos y asiáticos; la teosofía, cuyo despliegue en Argentina atrae hacia 1898 a figuras tales como Ingenieros, Alfredo Palacios y Leopoldo Lugones, y difunde una representación espiritista del Oriente gestada desde Occidente; y el movimiento literario modernista, que coloca en el centro del discurso los elementos estéticos y filosóficos de la cultura oriental, a través de la pluma de escritores tales como Joaquín V. González, Emilio Becher y Ángel de Estrada, como así también la presencia de ciertos tópicos anticolonialistas y antiimperialistas como el caso del cubano José Martí. De particular interés resulta la influencia de los motivos orientales en la obra de Lugones, que Bergel destaca, desde su doble inscripción tanto al modernismo literario como a la teosofía, en la cual participa activamente a través la Rama "Luz" y como una de las principales voces argentinas en la revista teosófica Philadelphia.

La tesis principal del autor se explicita en el capítulo III en donde muestra el modo en que el antiimperialismo de la década de 1920, en estrecha conexión con el reformismo universitario de América Latina y la Revolución Rusa, colabora a difundir una visión positiva de las luchas anticoloniales de países como la India, China, Turquía y Marruecos, las cuales son interpretadas como modelos a seguir en Argentina y en América Latina. Entre las principales vías de propagación de estos discursos se destacan el boletín Renovación -órgano de la Unión Latino Americana-, la Revista de Oriente perteneciente a la Asociación de Amigos de Rusia-, la revista platense Sagitario y el periódico de inclinación socialista Crítica. Estos dispositivos materiales contribuyen a configurar una red que forja lazos entre diversos intelectuales comprometidos con el antiimperialismo latinoamericano, entre ellos Ingenieros, Alfredo Palacios, Arturo Orzábal Quintana, Manuel Ugarte, Haya de la Torre, y figuras orientales identificadas con el movimiento anticolonial tales como el líder marroquí Abd-el-Krim y el líder del Kuomitang chino Sun Yat-sen.

Este capítulo marca un punto de inflexión en relación al concepto de Said ya que la motivación provocada por los casos de nacionalismo popular orientales quiebra la esencial oposición entre Oriente y Occidente y el interés de dominación implicado en el “orientalismo". Es en virtud del prisma antiimperialista, que permite congregar a países

\section{GANPHLAC}


de diferentes continentes en una empresa común, que el "orientalismo" logra un desplazamiento de sentido que circulará hasta la década de 1930. Este proceso se desarrolla conforme al desplazamiento de Europa como centro cultural para los intelectuales latinoamericanos, anunciado por el alemán Oswald Spengler en La decadencia de Occidente, y la configuración de un discurso referido al "Despertar de Oriente" cuyo principal divulgador en América Latina es Ernesto Quesada.

Sin embargo, este interés político por Oriente se produce en paralelo al surgimiento de una nueva discursividad sobre Oriente, de tipo espiritualista, fundada en la propuesta de un regreso a las dimensiones subjetivas de la experiencia como contrapartida de la ciencia y la cultura positivista. En el capítulo IV el autor advierte la circulación de este "Mensaje de Oriente", entre diversos intelectuales europeos y latinoamericanos, que convoca al Oriente a restituir los valores que Occidente había perdido. Figuras como Mahatma Gandhi, Romain Rolland y Rabindranath Tagore establecen vínculos con intelectuales argentinos como Manuel Gálvez, Joaquín V. González, Victoria Ocampo y así comienzan a circular diversas obras de escritores orientales a través de revistas teosóficas como ondas Bhuddicas y la estrella de occidente, y también en revistas de vanguardia literaria como Inicial y Martin Fierro.

El desplazamiento del foco de análisis desde los intelectuales argentinos hacia algunas figuras latinoamericanas, como José Vasconcelos, José Carlos Mariátegui y Haya de la Torre, le permite a Bergel afirmar no sólo la ya demostrada influencia de las luchas antiimperialistas orientales en Argentina sino la deuda que el surgimiento del movimiento nacional-popular latinoamericano mantiene con estos fenómenos orientales. Esto resulta visible en la posición del peruano Haya de la Torre, quien encuentra en el nacionalismo popular revolucionario del movimiento chino un ejemplo fundamental para la construcción de un movimiento de masas. Este descubrimiento, desarrollado en el capítulo V, resulta especialmente interesante ya que liga el discurso del "orientalismo invertido" con la idea de una comunidad de intereses entre América Latina y los países asiáticos y africanos que planteará el tercermundismo.

Por último, la tesis sobre la presencia de este "orientalismo invertido" se ve reforzada en el último capítulo al ser colocado como un foco de reacción para un conjunto de intelectuales nacionalistas católicos, entre ellos Manuel Gálvez, Juan Emiliano Carulla, Julio y Rodolfo Irazusta y César Pico, quienes emprenden una

\section{GANPHLAC}


iniciativa de restauración de la cultura occidental a fin de desplazar los elementos orientales.

A partir de lo expuesto podemos afirmar que Bergel realiza un aporte original al estado de la cuestión ya que, a partir de la hipótesis de Said, plantea la relectura de un proceso histórico y, junto a la clave teórica, muestra los nuevos hallazgos realizados mediante el estudio material de la circulación ideológica. 